\title{
PERILAKU POLITIK PEMILIH PEREMPUAN KOTA MOJOKERTO PADA PEMILU LEGISLATIF 2014
}

\author{
Irtanto \\ Badan Penelitian \& Pengembangan Provinsi Jawa Timur Jl. Gayung Kebonsari No. 56 Surabaya, telepon (031) \\ 8285671, fax 0318290719 No. HP. 081615256958 \\ Email: irtanto@rocketmail.com \\ Naskah diterima tanggal 13 Maret 2015, direvisi tanggal 20 Mei 2015, disetujui tanggal 3 November 2015
}

\section{POLITICAL BEHAVIOR OF WOMEN'S VOTER OF MOJOKERTO CITY ON LEGISLATIVE ELECTIONS 2014}

\begin{abstract}
The presence of democratization and the role of the mass media have an impact on the behavior of women voters. This research used a descriptive quantitative approach with the aim to identifying the role of institutions of socialization and media information on the legislative elections 2014, and to know the preferences of women's voter in determining their political choice and to know the exposure of mass media and the appeal of political advertising from political parties. The results indicate that the institution of socialization and information media on the legislative elections 2014 was instrumental in disseminating information and introduce the candidates to the voters. The preferences of women's voter in determining their political choices from the sociological side is more considering the religious background, professional organizations, origin of place, family information, and intellectuality of the candidates. From the psychological side, most women tend to consider the emotional closeness, similarity of political parties, the integrity, the same interest. The political preferences of rational considerations tend to the issue of the candidate experience and success in leading the organization, whether it locally or nationally, intellectuality and the quality of candidates, campaign issues, vision and mission, programs, credibility, commitment, personality, modest, good performance, good capability, clean image and performance, and closeness with ordinary people.
\end{abstract}

Keywords: legislative elections, political behavior, women's voter, the media and voter preferences.

\begin{abstract}
Abstrak
Kehadiran demokratisasi dan peran media massa berdampak terhadap perilaku pemilih perempuan. Penelitian ini menggunakan pendekatan deskritif kuantitatif dengan tujuan mengidentifikasi peran lembaga sosialisasi dan media informasi pada Pemilu Legislatif 2014, dan mengetahui preferensi pemilih perempuan dalam menentukan pilihan politiknya serta mengetahui terpaan media massa dan daya tarik iklan politik parpol. Hasil penelitian menunjukkan bahwa lembaga sosialisasi dan media informasi pada Pemilu Legislatif 2014 berperan dalam memberikan sosialisasi dan pengenalan kandidat kepada pemilih. Preferensi pemilih perempuan dalam menentukan pilihan politiknya dari sisi sosiologis lebih banyak mempertimbangkan latar belakang agama, organisasi profesi, asal daerah, informasi dari keluarga, dan intelektualitas kandidat. Dari sisi psikologis, kebanyakan perempuan cenderung mempertimbangkan kedekatan emosional, kesamaan parpol, integritas, minat yang sama.
\end{abstract}


Preferensi politik dari pertimbangan rasional cenderung kepada persoalan pengalaman dan keberhasilan kandidat dalam memimpin organisasi baik itu lokal maupun nasional, intelektualitas dan kualitas kandidat, isu-isu kampanye, visi dan misi, program kerja, kredibilitas, memunyai komitmen, kepribadian, gaya hidup sederhana, performa kinerja yang baik, kapabilitas yang bagus, kinerja/citra partai bersih, dan kedekatan dengan rakyat kecil.

Kata kunci: pemilu legislatif, perilaku politik, pemilih perempuan, media dan preferensi pemilih.

\section{PENDAHULUAN}

Penyelenggaraan Pemilu Legislatif tahun 2014 berdasarkan UU No. 8 Tahun 2012 tentang Pemilihan Umum Anggota DPR, DPD, dan DPRD. Pemilu Legislatif 2014 secara nasional diikuti oleh 12 partai yaitu Partai Nasdem, PKB, PKS, PDIP, Partai Golkar, Partai Gerindra, Partai Demokrat, PAN, PPP, Partai Hanura, Partai Bulan Bintang, dan Partai Keadilan dan Persatuan Indonesia (PKPI). Pemilu merupakan ruang terbuka bagi warga negara untuk memilih pilihan politiknya yaitu anggota legislatif pusat maupun daerah. Demikian sebaliknya calon anggota legislatif memberikan perhatiannya terhadap rakyat pemilihnya. Ketika ruang untuk bertarung menjadi terbuka, maka terjadilah perebutan pengaruh terhadap pemilih. Untuk memenangkan pertarungan politiknya dalam pemilu, siapa pun calon legislatif dan dari mana pun partainya akan membidik segmen pemilihnya dengan menebarkan janji-janji politiknya, isuisu, program kerja, dan sebagainya.

Demokrasi sebagai pilihan sistem politik Indonesia telah menempatkan semangat kebersamaan untuk mencapai kebaikan bersama. Kebersamaan politik dalam bentuk partisipasi politik telah menempatkan kesejajaran antara laki-laki dan perempuan dalam menentukan pilihan politiknya. Pemilu sebagai perwujudan demokrasi merupakan proses politik yang melibatkan seluruh warga negara baik itu laki-laki maupun perempuan. Idealnya demokrasi tidak membedakan antara laki-laki dan perempuan, mereka memunyai posisi yang sama dalam politik, memunyai hak pilih yang sama. Demokrasi tidak membedakan antara laki-laki dan perempuan. Namun demikian masih banyak yang mensinyalir bahwa perempuan ketinggalan dalam aktivitas politiknya, sampai-sampai Judith Squires dalam Rahmaturrizqi, dkk (2012) menyatakan bahwa perempuan telah lama dan secara luas mengalami ketinggalan dari berbagai aktivitas politik dan dihambat untuk mendefinisikan aktivitas mereka sebagai sesuatu yang menjadi bagian tidak terpisahkan dari politik. Dunia politik yang dianggap sebagai "dunia laki-laki" membuat perempuan masih enggan memasuki dunia politik karena bukan "dunia perempuan".

Kehadiran pemilih dalam pemilu dapat dipengaruhi pula oleh sejauhmana kandidat menawarkan format partisipasi publik, transparansi dalam penyelengaraan pemerintahan. Namun sayangnya pemilu legislatif hasil reformasi disinyalir telah melahirkan politik transaksional antara calon elit politik dengan pemilik hak pemilih. Akibatnya kekuatan modal telah merambah dan menjadi bagian yang tidak bisa terpisahkan dari mesin pemenangan pemilu legislatif. Tidak pelak para pemilih bersikap pragmatis dengan memertimbangkan keuntungan-keuntungan material daripada pertimbangan program sang kandidat. Kondisi politik yang demikian ini dapat berimplikasi terhadap perubahan perilaku politik masyarakat, dari idiologis ke pragmatisme.

Perilaku politik pemilihan legislatif dapat dipengaruhi oleh kampanye politik berupa program kandidat, dan politik transaksional yaitu kekuatan modal dapat pula diduga banyak dipengaruhi oleh sejauhmana peran media sosialisasi. Sosialisasi yang bertujuan untuk menyebarluaskan pelaksanaan pemilu sangat penting dilakukan dalam rangka meminimalisir golput. 
Permasalahan yang diteliti dalam penelitian ini adalah: 1. Sejauhmana peran lembaga sosialisasi dan media informasi pada pemilu legislatif 2014? 2. Bagaimana preferensi pemilih perempuan dalam menentukan pilihan politiknya terhadap kandidat anggota legislatif 2014? 3. Bagaimana terpaan media massa dan daya tarik iklan politik parpol pada pemilu legislatif 2014?

\section{LANDASAN KONSEP}

Perilaku politik oleh Surbakti (1992) didefinisikan sebagai kegiatan yang berkenaan dengan proses pembuatan dan keputusan politik. Lebih lanjut dalam tulisan ini merupakan tindakan ataupun kegiatan pemilih perempuan atau kelompok perempuan dalam kegiatan politik, yaitu Pemilihan Umum Legislatif 2014. Menurut Anwar dalam Irtanto (2014) bahwa “.....kelompok keagamaan, organisasi profesi, maupun pengelompokkan informal seperti keluarga, pertemanan, ataupun kelompok kecil lainnya memiliki peranan besar dalam membentuk sikap, persepsi, dan orientasi seseorang, yang nanti sebagai dasar atau preferensi dalam menentukan pilihan politiknya". Kemudian Gerald Pomper yang dikutip Asfar dalam Irtanto (2014) mencermati bahwa "preferensi-preferensi politik keluarga, apakah preferensi politik ayah atau preferensi politik ibu akan berpengaruh pada preferensi politik anak." Mark N. Franklin dalam Asfar (2006) memperkuat teori-teori sebelumnya ikatan sosiologis berpengaruh terhadap pilihan politik seseorang bahwa "ikatan-ikatan sosiologis ... secara teoritis masih cukup signifikan untuk melihat perilaku memilih."

Perilaku politik selain pendekatan sosiologis dapat pula didekati dengan pendekatan psikologis dan pilihan rasional. Pendekatan psikologis, Richard G.Niemi dan Herbert F. Weisberg seperti dikutip Asfar dalam Irtanto (2014) menjelaskan bahwa "sikap seseorang sebagai refleksi dari kepribadian seseorang, merupakan variabel yang cukup menentukan dalam memengaruhi perilaku politik seseorang". Ada tiga penekanan aspek dalam pendekatan psikologis yaitu "ikatan emosional pada suatu partai politik, orientasi terhadap isu-isu dan orientasi terhadap kandidat" (Asfar, 2006). Kemudian sikap dalam pendekatan psikologis Greenstien seperti yang dikutip Asfar (2006) memunyai tiga fungsi yaitu: "sikap merupakan fungsi kepentingan, sikap merupakan fungsi penyesuaian diri, sikap merupakan fungsi eksternalisasi dan pertahanan diri."

Faktor yang berpengaruh terhadap perilaku politik individu selain disebabkan oleh preferensi sosiologis, psikologis, dan pilihan rasional disebabkan pula oleh sejauh mana intensitas sosialisasi politik.

Sosialisasi dalam pemilu dapat dilakukan oleh berbagai lembaga termasuk media massa. Media massa memunyai peran yang sangat strategis, seperti apa yang dikatakan Nimmo dalam Irtanto (2013) bahwa "media adalah pembentuk pengetahuan, opini, dan keyakinan yang berpengaruh dan tidak dapat dihindari dalam masyarakat modern." Selanjutnya peran penting media massa memunyai kekuatan dalam memengaruhi pemilih, seperti yang diungkapkan Muhadi dalam Irtanto (2013) "media massa memiliki kekuatan pengaruh yang besar dalam ikut mengendalikan arah perubahan masyarakat, khususnya dalam kerangka politik. Apa yang dilakukan media adalah sesuatu yang menjadi perilaku politik masyarakat, baik perilaku mendukung atau menentang." Dengan melihat pentingnya media massa dalam pemilu yang dapat menjangkau kalangan luas sangat efektif untuk memengaruhi pemilih, oleh karena itu Firmansyah dalam Irtanto (2013) dalam menjalankan komunikasi politik agar lebih efektif tidak dapat meninggalkan peran media massa.

\section{METODE PENELITIAN}

Penelitian ini bersifat eksploratif dengan menggunakan pendekatan deskriptif 
kuantitatif dengan mengambil lokasi penelitian di Kota Mojokerto Jawa Timur yang terdiri dari dua kecamatan: Magersari dan Prajurit Kulon. Kecamatan Magersari dengan jumlah 10 kelurahan/desa, dan kecamatan Prajurit Kulon dengan jumlah 8 (delapan) kelurahan/desa. Jumlah pemilih pada Pemilu Legislatif 2014 sebanyak 93.521 orang yang diperebutkan oleh 12 partai politik. Masing-masing kelurahan/desa diambil sampel dengan quota sampling sebanyak 50 orang pemilih perempuan yang memilih dalam Pemilu Legisltif 2014. Jumlah sampel seluruhnya sebanyak 900 responden pemilih perempuan.

Pengumpulan data menggunakan teknik wawancara dengan instrumen daftar pertanyaan yang semi terstruktur baik tertutup maupun terbuka dengan mewawancarai pemilih perempuan pada Pemilu Legislatif 2014. Analisis data dalam penelitian ini lebih menekankan deskriptif kuantitatif. Tabel frekuensi digunakan dalam penelitian ini hanya untuk melihat kecenderungankecenderungan perilaku politik pemilih perempuan.

\section{HASIL PENELITIAN DAN PEMBAHASAN}

Kota Mojokerto terdiri dari dua kecamatan: Magersari dan Prajurit Kulon. Dari dua kecamatan tersebut diambil sampel penelitian sebanyak 900 responden perempuan yang memunyai hak pilih dalam Pemilu Legislatif 2014. Tempat tinggal responden kebanyakan di perkampungan $(61,20 \%)$ dan mereka yang bertempat tinggal di perumahan sebanyak $(38,8 \%)$. Sedangkan usia responden kebanyakan usia muda yaitu antara 15 s/d 40 tahun $(60,4 \%$ dan yang berusia 41 tahun ke atas sebanyak 39,6\%. Agama responden kebanyakan beragama Islam (88,8\%). Dari sisi pekerjaan kebanyakan sebagai ibu rumah tangga $(55,8 \%)$ sedangkan mereka yang bekerja sebanyak 44,2\%. Kemudian dari sisi pendidikannya $1,2 \%$ lulusan SD, lulus SMP
$4,0 \%$, lulus SLTA sebanyak $42,8 \%$, lulus akademi sebanyak $15,2 \%$, lulus sarjana/pasca sarjana sebanyak $36,8 \%$. Kemudian aktivitas responden sebanyak $42,8 \%$ menyatakan aktif di organisasi seperti LSM, partai politik, RT/RW, PKK, dan yang sebanyak 57,2\% menyatakan tidak aktif. Mereka aktif di organisasi sebagai pengurus $34,8 \%$, dan yang hanya sebagai anggota $(65,2 \%)$.

Responden penelitian pemilih perempuan memunyai latar belakang yang bervariasi. Mereka ada yang bertempat tinggal di perkampungan maupun perumahan; sebagai ibu rumah tangga maupun mereka yang bekerja atau wanita karier. Mereka berusia muda dan usia tua; Mereka berpendidikan lulusan SD, lulus SMP, lulus SLTA, lulus akademi dan lulus sarjana;

\section{Keterlibatan Dalam Pemilu}

Dalam Pemilu tahun 2014 mereka memilih kandidat sebanyak 95,0\%, sedangkan mereka yang tidak memilih hanya 5,0\%. Dalam Pemilu Legislatif 2014 dalam memilih anggota DPR atau DPRD tidaklah sama dalam setiap jenjang pilihan. Mereka yang memilih anggota DPRD Kota sama dengan DPRD Provinsi dan DPR RI sebanyak $21,0 \%$, mereka yang memilih anggota DPRD Kota sama dengan DPRD Provinsi sebanyak $10,85 \%$, mereka yang memilih anggota DPRD Kota sama dengan DPR sebanyak $17,8 \%$, sedangkan memilih anggota DPRD Kota berbeda pilihannya dengan DPRD Provinsi sebanyak 10,6\%, kemudian mereka yang memilih DPRD Kota berbeda dengan DPR sebanyak 7,8\%. Beragamnya pilihan politik perempuan pada pemilu legislatif 2014 tersebut menunjukkan kemandirian atau otonomi perempuan dalam memilih, artinya mereka tidak tergantung orang lain dalam memilihnya. Kondisi seperti ini sebagai dampak pengaruh media massa seperti yang diungkapkan Muhadi (dalam Irtanto, 2013) "media massa memiliki kekuatan pengaruh yang besar dalam ikut mengendalikan arah perubahan masyarakat, khususnya dalam kerangka politik." 


\section{Peran Lembaga Sosialisasi dan Media Informasi}

Dalam pemilihan anggota legislatif pada tahun 2014 peran lembaga sosialisasi maupun media informasi seperti media elektronika dan media cetak sangat berperan untuk meningkatkan partisipasi pemilih. Lembaga sosialisasi seperti KPU/KPUD/pers/TV dalam Pemilu Legislatif 2014 kebanyakan menilai sudah berperan/berjalan dengan baik (54,2\%), namun ada pula yang menilainya masih kurang berperan dengan baik (28,8\%). Bahkan mereka ada yang menilai masih tidak berperan $(2,0 \%)$. Di sisi lain yaitu pendidikan politik, lembaga sosialisasi tersebut dinilai oleh sebagian responden sudah memberikan pendidikan politik kepada masyarakat $(30,4 \%)$. Selain itu dinilai oleh sebagian besar responden masih kurang dalam memberikan pendidikan politik pada warga masyarakat $(52,6 \%)$. Bahkan ada pula mereka yang menilai tidak mendidik $(5,0 \%)$. Selama Pemilu Legislatif 2014 tidak semua pemilih perempuan mendapatkan sosialisasi, rincian datanya tertera pada tabel 1 (satu).

Hasil penelitian menunjukkan bahwa pemilih perempuan ada kecenderungan memberi penilaian bahwa lembaga sosialisasi sudah berperan, namun masih kurang memberikan pendidikan politik dan menyarankan sosialisasi tentang pemilu legislatif sebaiknya dilakukan oleh lembaga independen. Hasil penelitian ini mendukung teori Rush dan Althoff (2001) bahwa "sosialisasi politik bertujuan membentuk kepribadian politik dalam arti bahwa seseorang memperoleh orientasi politik yang memiliki tiga unsur: nilai-nilai dan keyakinan-keyakinan mendasar, pengetahuan dan informasi serta perspektif-perspektif politik, serta perasaan dan emosi berikut orientasi-orientasi politik, intensitas sosialisasi politik memengaruhi perilaku politik".

\section{Media Pengenalan Kandidat}

Kampanye pemilu legislatif 2014 oleh kandidat anggota legislatif sangat perlu diketahui oleh publik. Para kandidat diperkenalkan oleh berbagai media, baik itu media massa elektronik, maupun media massa berupa surat kabar, internet, selebaran/papan baliho, banner, kampanye rapat umum maupun lewat sarana yang lainnya. Berbagai media tersebut sangat penting perannya untuk memperkenalkan para kandidat di era pemilihan langsung ini. Tidak mengherankan media tersebut dipakai sebagai sarana untuk memperkenalkan oleh para kandidat anggota legislatif pusat, DPRD dan DPD, rincian datanya tertera pada tabel 2 (dua). Media pengenalan lainnya seperti kampanye rapat umum, teman sejawat, tetangga, organisasi keagamaan, rukun warga, partai politik, dan tim sukes/media interpersonal cenderung kurang efektif. Hal ini dapat dilihat bahwa para pemilih perempuan yang menyatakan mengenal kandidat anggota DPRRI dari masing-masing media tersebut prosentasinya tidaklah begitu signifikan.

Tabel 1

Pendapat Pemilih terhadap Peran Lembaga Sosialisasi

\begin{tabular}{|c|c|c|}
\hline No & Peran Lembaga Sosialisasi & $\begin{array}{c}\text { Frekuensi } \\
(\%)\end{array}$ \\
\hline 1 & Pemilih sudah cukup mendapatkan sosialisasi & 33,8 \\
\hline 2 & Pemilih belum cukup mendapatkan sosialisasi & 33,2 \\
\hline 3 & Pemilih kurang mendapatkan sosialisasi & 20,8 \\
\hline 4 & Pemilih tidak mendapatkan sosialisasi & 12,2 \\
\hline \multicolumn{2}{|c|}{ Total } & 100 \\
\hline
\end{tabular}

Sumber: Data primer diolah. 
Tabel 2

Media Informasi Kandidat Anggota DPRRI, DPRD Provinsi, DPRD Kota Mojokerto

\begin{tabular}{llccc}
\hline No & Media Pengenalan & \multicolumn{3}{c}{ Kandidat anggota legislatif (\%) } \\
\cline { 3 - 5 } & & 72,2 & 16,6 & 11,2 \\
\hline 1 & Iklan televisi & 18,8 & 43,2 & 38,0 \\
2 & Media radio & 31,8 & 31,2 & 28,0 \\
3 & Surat kabar harian (koran) & 28,8 & 21,0 & 17,2 \\
4 & Televisi \& radio & 32,8 & 21,8 & 20,4 \\
5 & Internet & 44,8 & 30,4 & 65,8 \\
6 & Selebaran/papan baliho, banner & 17,6 & 17,2 & 29,2 \\
7 & Kampanye rapat umum & 21,0 & 22,4 & 28,0 \\
8 & Teman sejawat & 15,2 & 21,4 & 34,6 \\
9 & Tetangga & 5,4 & 19,4 & 39,0 \\
10 & Organisasi keagamaan & 9,4 & 4,8 & 19,4 \\
11 & Perkumpulan warga & 14,6 & 25,0 & 38,2 \\
12 & Partai politik & 22,8 & 25,2 & 51,8 \\
\hline 13 & Tim sukses/komunikasi interpersonal & & & DPRD Kota \\
\hline
\end{tabular}

Sumber: Data primer diolah (kuesioner pilihan ganda).

Media massa dalam Pemilu Legislatif 2014 tampak efektif untuk memengaruhi pemilih perempuan di Kota Mojokerto, hal ini diketahui dari hasil penelitian yang memerlihatkan bahwa sebagian besar mereka mengenal kandidat melalui media massa, baik cetak maupun elektronika. Kondisi ini relevan dengan teori yang dikemukan oleh Wiryanto (2000) yang menyatakan bahwa adapun definisi efek adalah semua jenis perubahan yang terjadi dalam diri penerima, setelah menerima pesan dari suatu sumber. Perubahan tersebut meliputi perubahan pengetahuan, perubahan sikap, dan perubahan perilaku nyata (Wiryanto, 2000).

Kemudian pemilih perempuan pada Pemilu Legislatif 2014 mengenal anggota DPRD lewat berbagai media, rincian datanya tertera pada tabel 2 (dua). Data ini menunjukkan bahwa pemilih perempuan Kota Mojokerto dalam mengenal para kandidat anggota DPRD Provinsi Jawa Timur tidak ada media pengenalan yang dominan, hal ini terlihat masing-masing media pengenalan diketahui oleh pemilih perempuan rata-rata masih di bawah 50\% dan rata-rata mereka mengenal anggota DPRD Provinsi melalui media yang variatif. Selanjutnya pemilih perempuan Kota Mojokerto mengenal kandidat anggota DPRD Kota Mojokerto melalui berbagai media iklan televisi, media radio, surat kabar atau koran lokal, media televisi dan radio, internet, selebaran/papan baliho/banner, kampanye rapat umum, teman sejawat, tetangga, organisasi keagamaan, perkumpulan warga, partai politik dan tim sukses/komunikasi interpersonal, rincian datanya tertera pada tabel 2 (dua).

Ada kencenderungan bahwa perilaku politik pemilih perempuan dipengaruhi oleh media massa, mereka mengenal kandidat karena faktor iklan televisi, radio, surat kabar, media internet, baliho/banner. Realitas penelitian ini menunjukkan bahwa kuatnya peran media massa, dan media massa memunyai peran yang sangat strategis. Kondisi ini mendukung teori Nimmo (1989) bahwa media massa memunyai peran yang sangat strategis, "media adalah pembentuk pengetahuan, opini, dan keyakinan yang berpengaruh dan tidak dapat dihindari dalam masyarakat modern." Demikian juga teori Muhtadi (2008), "media massa memiliki kekuatan pengaruh yang besar dalam ikut 
mengendalikan arah perubahan masyarakat, khususnya dalam kerangka politik. Apa yang dilakukan media adalah sesuatu yang menjadi perilaku politik masyarakat, baik perilaku mendukung atau menentang".

\section{Preferensi Pemilih Dalam Memilih Kandidat}

Pemilih perempuan Kota Mojokerto pada Pemilu 2014 dalam memberikan pilihan politiknya memiliki bermacam-macam pertimbangan yakni pertimbangan sosiologis, psikologis dan pertimbangan rasional.

\section{Pilihan Sosiologis}

Pemilih perempuan dalam memberikan pilihan politiknya tidak lepas mempertimbangan latar belakang sosiologis, datanya terlihat pada tabel 3 (tiga).

Preferensi pemilih perempuan dilihat dari sisi sosiologis dalam Pemilu Legislatif 2014 mencerminkan masih dominan. Kondisi ini sependapat dengan Anwar (2006) yang menyatakan bahwa "pemahaman terhadap pengelompokkan sosial baik secara formal, seperti kelompok keagamaan, organisasi profesi, maupun pengelompokkan informal seperti keluarga, pertemanan, ataupun kelompok kecil lainnya memiliki peranan besar dalam membentuk sikap, persepsi, dan orientasi seseorang, sebagai dasar atau preferensi dalam menentukan pilihan politiknya."

Dalam Pemilu Legislatif 20014 saran dan informasi dari seorang teman tidaklah efektif untuk memengaruhi pemilih perempuan, rincian datanya terlihat pada tabel 3 (tiga).

Tidak selamanya bahwa pemilih perempuan dalam menentukan pilihan politiknya tidak hanya karena dipengaruhi oleh isu politik, kesopanan serta tidak hanya karena tingkat pendidikannya. Namun lebih dari itu menurut Marc J Hetherington seperti dikutip Asfar dalam Irtanto (2012) bahwa "penilaian terhadap isu dan kandidat bukanlah sesuatu yang terjadi secara tiba-tiba, namun sering dipengaruhi oleh informasi yang diterima pemilih melalui media massa yang diikutinya."

Hasil penelitian memunyai kecenderungan bahwa latar belakang sosiologis masih menjadi dominan dalam menentukan pilihan politik perempuan seperti latar belakang agama, kesamaan jenis kelamin, asal daerah, organisasi profesi dan lain sebagainya. Kondisi ini menunjukkan bahwa teori sosiologis masih relevan untuk menjelaskan pilihan politik perempuan dalam Pemilu Legislatif 2014 seperti teori yang dikemukakan oleh Anwar (2006) bahwa kelompok keagamaan, organisasi profesi, maupun pengelompokan informal seperti keluarga, pertemanan, ataupun kelompok kecil lainnya memiliki peranan besar dalam membentuk sikap, persepsi, dan orientasi seseorang, yang nanti sebagai dasar atau preferensi dalam menentukan pilihan politiknya.

\section{Pilihan Psikologis}

Pada Pemilu Legislatif 2014 pemilih perempuan Kota Mojokerto dalam mempertimbangkan untuk memilih pilihannya secara psikologis bervariasi, datanya terlihat pada tabel 4 (empat).

Ada kecenderungan hasil penelitian menunjukkan bahwa pertimbangan psikologis yang menjadi pilihan pemilih perempuan adalah kedekatan emosional seperti keluarga, ikatan alumni sekolah atau perguruan tinggi, asal partai politik yang sama mereka senangi, kesalehan kandidat, memunyai jabatan formal, mereka memunyai integritas dan berpenampilan menarik. Kondisi ini mendukung pendekatan psikologis teori Richard G Niemi dan Herbert F Weisberg dikutip Asfar dalam Irtanto (2014) yang menjelaskan bahwa sikap seseorang sebagai refleksi dari kepribadian seseorang, merupakan variabel yang cukup menentukan dalam memengaruhi perilaku politik seseorang. 
Tabel 3

Pertimbangan Sosiologis dalam Memilih Kandidat

\begin{tabular}{llcccc}
\hline No & Latar belakang pilihan & \multicolumn{4}{c}{ Pertimbangan Memilih (\%) } \\
\cline { 3 - 6 } & & $\begin{array}{c}\text { Dipertimba } \\
\text { ngkan }\end{array}$ & $\begin{array}{c}\text { Tidak } \\
\text { dipertimbangkan }\end{array}$ & $\begin{array}{c}\text { Tidak tahu } \\
\text { menahu }\end{array}$ & $\begin{array}{c}\text { Jumlah } \\
(\%)\end{array}$ \\
\hline 1 & Latar belakang agama & 70,6 & 21,2 & 8,2 & 100 \\
2 & Berasal dari organisasi profesi & 52,8 & 38,6 & 8,4 & 100 \\
3 & Kesamaan jenis kelamin (gender) & 20,8 & 62,2 & 17,0 & 100 \\
4 & Asal dari daerah/asli & 51,6 & 39,2 & 8,2 & 100 \\
5 & Berasal dari keturunan pemimpin & 44,6 & 49,2 & 6,2 & 100 \\
6 & Berasal dari ulama/rohaniawan & 33,8 & 54,4 & 11,8 & 100 \\
7 & Saran, informasi dari keluarga (ayah, & 51,2 & 38,8 & 10,0 & 100 \\
& suami dll) & & & & \\
8 & Saran dan informasi dari teman & 38,2 & 56,8 & 5,0 & 100 \\
9 & Saran dari tokoh agama & 38,8 & 54,8 & 6,4 & 100 \\
10 & Berasal dari latar belakang tokoh & 25,6 & 63,2 & 11,2 & 100 \\
& militer & & & & \\
11 & Kesopanan/sopan santun dalam & 75,6 & 24,2 & 10.4 & 100 \\
& pergaulan/menghargai orang lain & & & & 100 \\
12 & Usia kematangan calon legislatif & 70,4 & 17,2 & 12,4 & 100 \\
13 & Pendidikan/intelektual seorang calon & 76,2 & 16,8 & 7,0 & 100 \\
\hline 14 & Pilihan sama orang tua (ayah, ibu) & 32,2 & 55,6 & 12,4 & \\
\hline
\end{tabular}

Sumber: data primer diolah.

\section{Pilihan Rasional}

Pemilih perempuan Kota Mojokerto selain pertimbangan sosiologis dan psikologis dalam memilih kandidat anggota legislatif juga mempertimbangkan hal-hal yang bersifat rasional, lihat tabel 5 .

Hasil penelitian yang menunjukkan bahwa pilihan rasional pemilih perempuan dalam Pemilu Legislatif 2014 ada kecenderungan memilih kandidat karena pertimbangan pengalaman dan keberhasilan memimpin organisasi, status pendidikan atau intelektualitas/kualitas SDM kandidat, mempunyai visi dan misi, professional dan mempunyai kredibilitas, melihat partainya yang mempunyai citra yang baik. Kondisi ini relevan dengan teori pendekatan pilihan rasional Surbakti (1992) yang menyatakan bahwa "bagi pemilih, pertimbangan untung dan rugi digunakan untuk membuat keputusan tentang kandidat yang dipilih, terutama untuk membuat keputusan apakah ikut memilih atau tidak ikut memilih."

\section{Terpaan dan Penampilan Iklan Politik Terpaan Iklan Partai Politik}

Partai politik ataupun kandidat harus mampu mengemas iklan politik sehingga mereka tertarik untuk melihatnya. Ada dugaan sementara bahwa mereka yang sering melihat iklan politik ada kecenderungan tertarik pada iklan tersebut dan sebaliknya bila mereka atau pemilih jarang sekali melihat iklan politik ada kemungkinan mereka kurang tertarik pada iklan tersebut. Kemudian sejauh mana frekuensi iklan politik yang ditampilkan tersebut dapat dilihat atau dinikmati oleh para pemilihnya? Terpaan iklan politik tersebut dapat diduga akan memengaruhi perilaku politik para pemilih. Berikut ini ditampilkan iklan politik yang ditampilkan oleh partai politik peserta pemilu anggota 
legislatif 2014 lihat tabel 6 (enam). Dari data yang diperoleh bahwa ada empat partai yang dominan yang sering dilihat oleh pemilih perempuan Kota Mojokerto, yaitu iklan politik dari Partai Demokrat, PDI-P, Partai Gerindra dan Partai Golkar. Peran iklan politik pada media massa ternyata sering dilihat oleh pemilih perempuan. Hal ini menandakan bahwa iklan politik ini dapat diperkirakan memengaruhi opini pemilih, paling tidak citra partai politik menjadi lebih positip atau negatif. Kondisi ini memperkuat teori Nimmo (1993) bahwa "media adalah pembentuk pengetahuan, opini, dan keyakinan yang berpengaruh dan tidak dapat dihindari dalam masyarakat modern."
Iklan politik dari partai lainnya ada yang sering dilihat ada pula yang mereka kadang-kadang melihatnya, lihat tabel 6 (enam). Iklan politik menjadi peran yang sangat penting dalam Pemilu Legislatif 2014. Iklan politik yang diperankan oleh media massa dapat memengaruhi perilaku politik yang melihatnya, kondisi ini mendukung teori Muhtadi (2008) yang menyatakan bahwa "media massa memiliki kekuatan pengaruh yang besar dalam ikut mengendalikan arah perubahan masyarakat, khususnya dalam kerangka politik. Apa yang dilakukan media adalah sesuatu yang menjadi perilaku politik masyarakat, baik perilaku mendukung atau menentang."

Tabel 4

Pertimbangan Psikolgis Dalam Pemilu Legislatif 2014

\begin{tabular}{|c|c|c|c|c|c|}
\hline \multirow{2}{*}{ No } & \multirow[t]{2}{*}{ Latar belakang pilihan } & \multicolumn{3}{|c|}{ Pertimbangan Memilih (\%) } & \multirow{2}{*}{$\begin{array}{c}\text { Jumlah } \\
(\%)\end{array}$} \\
\hline & & Dipertimbangkan & $\begin{array}{c}\text { Tidak } \\
\text { dipertimbangkan }\end{array}$ & $\begin{array}{l}\text { Tidak tahu } \\
\text { menahu }\end{array}$ & \\
\hline 1 & $\begin{array}{ll}\text { Kedekatan } & \text { emosional } \\
\text { (keluarga, alumni) } & \end{array}$ & 52,6 & 37,2 & 10,2 & 100 \\
\hline 2 & Kesamaan parpol & 60,6 & 38,2 & 1,2 & 100 \\
\hline 3 & Saran atasan dalam bekerja & 12,0 & 65,2 & 22,8 & 100 \\
\hline 4 & Kesalehan kandidat & 60,2 & 20,8 & 19,0 & 100 \\
\hline 5 & $\begin{array}{lll}\text { Jabatan } & \text { formal dalam } \\
\text { organisasi } & & \end{array}$ & 52,8 & 23,8 & 23,4 & 100 \\
\hline 6 & $\begin{array}{l}\text { Popularitas kandidat (artis, } \\
\text { dsb) }\end{array}$ & 24,2 & 55,2 & 20,6 & 100 \\
\hline 7 & $\begin{array}{ll}\text { Penampilan } & \text { berpakaian: } \\
\text { kerapian, } & \text { keanggunan } \\
\text { berpakaian } & \end{array}$ & 65,2 & 16,8 & 18,0 & 100 \\
\hline 8 & $\begin{array}{l}\text { Penampilan fisik:ketampanan, } \\
\text { kecantikan }\end{array}$ & 32,2 & 51,4 & 16,4 & 100 \\
\hline 9 & Integritas yang baik & 78,4 & 3,8 & 17,8 & 100 \\
\hline 10 & $\begin{array}{l}\text { Punya minat yang sama } \\
\text { dengan kandidat legislatif }\end{array}$ & 58,2 & 22,8 & 19,0 & 100 \\
\hline 11 & $\begin{array}{l}\text { Kenal secara personal } \\
\text { (sahabat, teman, tetangga) }\end{array}$ & 32,2 & 46,6 & 21,2 & 100 \\
\hline 12 & $\begin{array}{l}\text { Kenal (tahu) tetapi tidak kenal } \\
\text { secara personal }\end{array}$ & 32,6 & 45,2 & 22,2 & 100 \\
\hline
\end{tabular}

Sumber: data primer diolah. 
Tabel 5

Pertimbangan Rasional Dalam Pemilu Legislatif 2014

\begin{tabular}{llcccc}
\hline \multirow{2}{*}{ No } & Latar belakang pilihan & \multicolumn{2}{c}{ Pertimbangan Memilih (\%) } & $\begin{array}{c}\text { Jumlah } \\
\text { (\%) }\end{array}$ \\
\cline { 3 - 5 } & Dipertimbangan & $\begin{array}{c}\text { Tidak } \\
\text { dipertimbangkan }\end{array}$ & $\begin{array}{c}\text { Tidak } \\
\text { tahu }\end{array}$ & \\
\hline 1 & Pengalaman dan keberhasilan & 80,6 & 10,2 & 9,2 & 100 \\
& memimpin organisasi & & & & \\
2 & Status pendidikan/intelektual & 70,2 & 17,6 & 12,2 & 100 \\
3 & Pengusaha/status ekonomi & 34,2 & 53,6 & 12,2 & 100 \\
4 & Professional & 52,2 & 34,6 & 13,2 & 100 \\
5 & Pensiunan dari birokrat/ & 54,2 & 33,2 & 12,6 & 100 \\
& pemerintahan & & & & \\
6 & Isu-isu kampanye & 46,4 & 37,2 & 16,4 & 100 \\
7 & Visi dan misi kandidat & 76,4 & 13,4 & 10,2 & 100 \\
8 & Kredibilitas kandidat & 65,0 & 19,8 & 15,2 & 100 \\
9 & Program kerja kandidat & 72,6 & 17,2 & 10,2 & 100 \\
10 & Kualitas SDM & 72,4 & 15,8 & 11,8 & 100 \\
11 & Komitmen untuk membangun & 74,2 & 17,4 & 8,4 & 100 \\
12 & Gaya hidup sederhana, bersahaja & 74,4 & 16,8 & 8,8 & 100 \\
13 & Performa kinerja yang baik & 75,4 & 16,8 & 7,8 & 100 \\
14 & Performa kapabilitas yang bagus & 69,4 & 19,8 & 10,8 & 100 \\
15 & Kinerja partai/citra partai & 56,6 & 33,2 & 10,2 & 100 \\
16 & Kedekatan dengan rakyat kecil & 68,6 & 20,8 & 10,6 & 100 \\
\hline
\end{tabular}

Sumber: data primer diolah.

\section{Penampilan Iklan Politik Parpol}

Penampilan iklan politik dari masingmasing partai politik peserta pemilihan umum legislatif 2014 dapat diduga akan memengaruhi perilaku politik pemilih perempuan di Kota Mojokerto. Penampilan iklan politik di televisi, surat kabar, maupun berbentuk baliho ataupun banner dikemas semenarik mungkin dengan tujuan agar para pemirsa tertarik untuk memilihnya. Oleh karena itu penampilan iklan politik menjadi sangat penting karena memunyai dampak atau efek terhadap perilaku politik pemilih. Paling tidak akan dijadikan rujukan atau pertimbangan dalam memilihnya. Dari data yang sajikan dalam tabel 7 (tujuh) memerlihatkan bahwa iklan politik yang ditampilkan oleh masing-masing partai politik memunyai daya tarik tersendiri di mata pemilih perempuan Kota Mojokerto. Hasil penelitian ini menunjukkan bahwa iklan politik yang ditampilkan oleh partai politik cenderung dinilai menarik, baik itu dalam bentuk isu-isu politik maupun iklan politik dalam bentuk program. Kondisi ini relevan dengan teori pilihan rasional Marc $\mathbf{J}$ Hetherington seperti dikuti Asfar dalam Irtanto (2012) bahwa pemilih dalam menentukan pilihan politiknya didasarkan atas penilaian terhadap isu-isu politik dan kandidat yang diajukan. Penilaian terhadap isu dan kandidat bukanlah sesuatu yang terjadi secara tiba-tiba, namun sering dipengaruhi oleh informasi yang diterima pemilih melalui media massa yang diikutinya.

Penampilan iklan politik Partai Demokrat dipandang menarik karena dapat menunjukkan kinerja pemerintahannya, sedangkan mereka yang memandang tidak menarik salah satunya adalah lebih 
disebabkan karena realitasnya orang-orang di partainya banyak terlibat korupsi. Penampilan iklan politik PDI-P dipandang oleh pemilih perempuan kebanyakan menarik, salah satunya bisa menggambarkan realita orangorang kecil yang kurang mendapat perhatian dari pemerintah. Demikian juga penampilan iklan politik dari Partai Gerindra dipandang oleh sebagian besar pemilih perempuan di Kota Mojokerto menarik karena Partai Gerindra ini relatif partai baru yang dipandang cukup berhasil dalam menggerakkan massa, dengan menampilkan iklan politiknya yang menggambarkan citacita masa depan bangsa yang perlu diraih. Partai tersebut realistis dengan menampilkan program kerja dan yang perlu dikerjakan oleh partainya bersama rakyatnya.

Dalam penelitian ini menunjukkan bahwa pemilih perempuan memunyai kemampuan untuk menilai bagaimana penampilan iklan politik dari masing-masing partai politik. Kondisi ini mencerminkan media massa efektif untuk menawarkan program-programnya. Efektif tidaknya media massa dalam menyampaikan pesan, tentunya tidak lepas dari bagaimana proses penerimaan pesan. Media massa memiliki efek, tetapi penerimaan efek itu juga dipengaruhi faktor lain, seperti tingkat pendidikan, lingkungan sosial, kebutuhan, dan sistem nilai yang dianut. Semakin tinggi tingkat pendidikan individu, semakin selektif untuk menerima pesan-pesan media massa (Kriyantoro, 2008)

Selain itu penampilan iklan politik yang dipandang oleh kebanyakan pemilih perempuan menarik $(61,2 \%)$ adalah iklan politik Partai Golkar. Mereka yang memandang iklan politik Partai Golkar menarik lebih disebabkan partai tersebut antara lain realitis yang menggambarkan kondisi bangsa Indonesia, dan banyak menampilkan variasi program-programnya. Sedangkan iklan politik Partai Nasdem, ada sebagian memandang menarik $(38,2 \%)$, ada pula mereka yang sebagian memandang iklan politiknya tidak menarik $(26,0 \%)$. Namun mereka ada yang tidak tahu menahu iklan politik Partai Nasdem menarik ataukah tidak menarik. Dari 12 partai politik peserta pemilu. legislatif 2014, banyak iklan politik yang dipandang oleh pemilih perempuan Kota Mojokerto ada kecenderungan tidak menarik seperti efektivitas komunikasi politik

Tabel 6

Iklan Politik dan Partai Politik

\begin{tabular}{llcccc}
\hline No & Partai Politik & \multicolumn{3}{c}{ Iklan politik yang dilihat $(\%)$} & Jumlah \\
\cline { 2 - 4 } & & Sering & Kadang-kadang & Tidak tahu & $(\%)$ \\
\hline 1 & Partai Demokrat & 72,4 & 17,8 & 9,8 & 100 \\
2 & PDI-P & 59,4 & 26,8 & 13,8 & 100 \\
3 & Partai Gerindra & 66,6 & 15,8 & 17,6 & 100 \\
4 & Partai Golkar & 62,2 & 19,2 & 18,6 & 100 \\
5 & PPP & 22,2 & 34,6 & 43,2 & 100 \\
6 & PKB & 31,6 & 34,4 & 34,0 & 100 \\
7 & Partai Hanura & 37,4 & 36,8 & 25,8 & 100 \\
8 & PKS & 24,6 & 35,2 & 40,2 & 100 \\
9 & PAN & 34,0 & 31,2 & 33,8 & 100 \\
10 & PKPI & 9,0 & 36,0 & 58,0 & 100 \\
11 & PBB & 8,2 & 37,8 & 54,0 & 100 \\
12 & Partai Nasdem & 30,4 & 38,8 & 30,8 & 100 \\
\hline
\end{tabular}

Sumber: data primer diolah 
Tabel 7

Daya Tarik Iklan Politik Partai Peserta Pemilu 2014

\begin{tabular}{llcccc}
\hline \multirow{2}{*}{ No } & Partai Politik & \multicolumn{2}{c}{ Ketertarikan Terhadap Iklan Politik (\%) } & Jumlah \\
\cline { 3 - 4 } & & Menarik & Tidak Menarik & Tidak Tahu & $(\%)$ \\
\hline 1 & Partai Demokrat & 58,2 & 22,8 & 19,0 & 100 \\
2 & PDI-P & 54,6 & 25,2 & 20,2 & 100 \\
3 & Partai Gerindra & 60,6 & 20,4 & 19,0 & 100 \\
4 & PPP & 15,6 & 31,2 & 53,2 & 100 \\
5 & PKB & 19,8 & 35,2 & 45,0 & 100 \\
6 & Partai Hanura & 31,2 & 39,2 & 29,6 & 100 \\
7 & PKS & 16,2 & 37,2 & 46,6 & 100 \\
8 & PAN & 23,4 & 28,8 & 47,8 & 100 \\
9 & PKPI & 6,0 & 35,2 & 58,8 & 100 \\
10 & PBB & 12,0 & 33,4 & 54,6 & 100 \\
11 & Partai Nasdem & 38,2 & 26,0 & 35,8 & 100 \\
12 & Partai Golkar & 61,2 & 12,8 & 26,0 & 100 \\
\hline
\end{tabular}

Sumber: Data primer diolah.

membutuhkan peran serta media massa, karena merekalah salah satu profesi penting yang memiliki perangkat dan kemampuan berkomunikasi dengan masyarakat luas. Iklan politik dari PPP, PKB, Partai Hanura, PKS, PAN, PKPI dan PBB. Bahkan banyak pula mereka yang tidak tahu menahu iklan politik partai-partai tersebut.Walaupun demikian ada pula sebagian kecil dari mereka yang menilai menarik.

Hasil penelitian ini dapat dipahami bahwa media massa memunyai peran penting untuk memengaruhi pemilih, seperti apa yang dikatakan Firmansyah (2008) bahwa "efektivitas komunikasi politik membutuhkan peran serta media massa, karena merekalah salah satu profesi penting yang memiliki perangkat dan kemampuan berkomunikasi dengan masyarakat luas".

\section{PENUTUP}

\section{Simpulan}

Peran lembaga sosialisasi dan media informasi pada pemilu legislatif 2014 seperti media elektronika dan media cetak sangat berperan dalam meningkatkan partisipasi pemilih. Lembaga sosialisasi seperti KPU/KPUD, surat kabar, televisi kebanyakan dinilai sudah berperan dengan baik, memberi sosialisasi dan memberikan pendidikan politik kepada masyarakat. Media informasi sebagai media pengenalan kandidat DPRRI kebanyakan berasal dari iklan televisi, surat kabar, radio, internet, selebaran/papan baliho/banner. Kemudian DPRD Provinsi Jawa Timur kebanyakan dari media radio, surat kabar (koran), selebaran/baliho/banner. Selanjutnya DPRD Kota Mojokerto dikenal kebanyakan melalui media radio lokal, selebaran/baliho/banner, tetangga, organisasi keagamaan, partai politik dan tim sukses/komunikasi interpersonal.

Preferensi pemilih perempuan dalam menentukan pilihan politiknya terhadap kandidat anggota legislatif 2014 dari sisi sosiologis lebih banyak pertimbangkan latar belakang agama, organisasi profesi, asal daerahnya, saran atau informasi dari keluarga, kesopanan dan menghargai orang lain dalam pergaulan, usia kematangan dan intelektualitas kandidat. Kemudian dari sisi psikologis dalam memilih kebanyakan lebih cenderung mempertimbangkan kedekatan 
emosional (keluarga, alumni), kesamaan partai politik yang mereka senangi, penampilan berpakaian, integritas yang baik, mempunyai minat yang sama dengan kandidat anggota legislatif. Preferensi politik dari pertimbangan rasional para pemilih perempuan cenderung kepada persoalan pengalaman dan keberhasilan kandidat dalam memimpin organisasi baik itu lokal maupun nasional, intelektualitas dan kualitas kandidat, isu-isu kampanye, visi dan misi, program kerja kandidat, kredibilitas, mempunyai komitmen untuk membangun bangsa, kepribadian, gaya hidup sederhana dan bersahaja, performa kinerja yang baik, kapabel, kinerja/citra partai yang baik/bersih, dan kedekatan kandidat dengan rakyat kecil.

Dalam Pemilu Legislatif 2014 media masa memunyai peran yang penting dengan frekuensi pemberitaan persoalan pemilu yang relatif tinggi, sehingga masyarakat mudah untuk mengetahui/melihatnya bagaimana partai politik mengampanyekan programprogram dan kandidatnya. Para pemilih perempuan di Kota Mojokerto yang sering melihat berbagai iklan politiknya antara lain Partai Demokrat, PDI-P, Partai Gerindra Partai Golkar dan Partai Hanura. Dari iklan politik yang sering ditampilkan di media massa tersebut yang memunyai daya tarik tersendiri. Para pemilih perempuan kebanyakan menganggap iklan politik yang menarik adalah iklan politik Partai Demokrat, PDI-P, dan Partai Gerindra.

\section{DAFTAR PUSTAKA}

Anwar, M. Khoirul dkk. (2006). Perilaku Partai Politik,: Studi Perilaku Partai Politik dalam Kampanye dan Kecenderungan Pemilih pada Pemilu 2004. Malang: Universitas Muhammadyah.

Asfar, Muhammad. (2006). Pemilu dan Perilaku Memilih 1955-2004. Surabaya: Pustaka Eureka.
Kriyantono, Rachmat. (2008). Teknik Praktis Riset Komunikasi. Jakarta: Kencana.

Mc Quail, Dennis. (1996). Teori Komunikasi Massa. Jakarta: Erlangga.

Muhtadi, Asep Saeful. (2008). Komunikasi Politik di Indonesia: Dinamika Islam Politik Pasca Orde Baru. Bandung: Remaja Rosdakarya.

Nimmo, Dan. (1989). Komunikasi Politik, Khalayak dan Efek. Bandung: Rosdakarya. .(1993). Komunikasi Politk, Komunikator, Pesan, dan Media. Bandung: Rosdakarya

Nurudin. (2007). Pengantar Komunikasi Massa. Jakarta: PT. Raja Grafindo Persada

Rakhmat, Jalahuddin. (1998). Psikolgi Komunikasi. Bandung: Remaja Rosdakarya.

Rush, Michael dan Althoff, Philip. (2001). Pengantar Sosiologi Politik. Jakarta: PT. Raja Grafindo Persada.

Surbakti, Ramlan. (1992). Memahami Ilmu Politik. Jakarta: Gramedia Widiasarana.

Wiryanto. (2000). Teori Komunikasi Massa. Jakarta: PT. Grasindo.

\section{Jurnal:}

Irtanto. (2009). Perilaku Politik Pemilih Pada Pemilihan Gubernur Jawa Timur Periode 2008-2013. Jurnal Komunikasi. 12(1), hal. 43-62.

--. (2012). Daya Tarik Iklan Politik Pada Pemilu Legislatif. Jurnal Penelitian Komunikasi. 15(1) Juli, hal. 67-78.

--------. (2014). Political Behavior Of Voters on Mayoral Election of Kediri East Java, Indonesia. Academic Research International. 5(2) March, pp. 309-324.

--------. (2014). Role of Mass Media to Political Participation on the Mayoral Election of Kediri East Java, Indonesia. Academic Research International 5(6) November, pp.211-225.

Rahmaturrizqi, dkk. (2012). Gender dan Perilaku Memilih: Sebuah Kajian Psikologi Politik [internet]. Jurnal 
Psikologi Teori dan Terapan. 3(1), hal.

49-57. Tersedia dalam:

<http://ejournal.unesa.ac.id/index.php/j

urnal_jptt> [diakses 1 Januari 2015]. 